\title{
GLP-1 and exendin-4 can reverse hyperlipidic-related osteopenia
}

\author{
Bernardo Nuche-Berenguer ${ }^{1}$, Daniel Lozano ${ }^{2}$, Irene Gutiérrez-Rojas ${ }^{1}$, Paola Moreno', \\ María L Mariñoso ${ }^{3}$, Pedro Esbrit ${ }^{2, *}$ and María L Villanueva-Peñacarrillo ${ }^{1, *}$ \\ ${ }^{1}$ Department of Metabolism, Nutrition and Hormones and ${ }^{2}$ Bone and Mineral Metabolism Laboratory, Instituto de Investigación Sanitaria (IIS)-Fundación \\ Jiménez Díaz, Avda Reyes Católicos 2, 28040 Madrid, Spain \\ ${ }^{3}$ Department of Pathology, Hospital del Mar, 08003 Barcelona, Spain \\ (Correspondence should be addressed to M L Villanueva-Peñacarrillo; Email: mlvillanueva@fjd.es) \\ *(P Esbrit and M L Villanueva-Peñacarrillo contributed equally to this work)
}

\begin{abstract}
Increased fat mass contributes to bone deterioration. Glucagon-like peptide 1 (GLP-1) and its related peptide exendin 1-39 amide (Ex-4), two lipid-lowering peptides, exert osteogenic effects in diabetic states. We examined the actions of 3-day administration of GLP-1 or Ex-4 on bone remodeling markers and on bone mass and structure in hyperlipidic (HL) and hypercaloric rats. Wistar rats on a hyperlipidemic diet for 35 days were subcutaneously administered GLP-1 $(0.86 \mathrm{nmol} / \mathrm{kg}$ per h), Ex-4 $(0 \cdot 1 \mathrm{nmol} / \mathrm{kg}$ per $\mathrm{h})$, or saline (control) by continuous infusion for 3 days. After killing, tibiae were removed for total RNA and protein isolation, as well as femurs and L1-L4 vertebrae for bone mass and quality assessment. Body weight and plasma insulin were unaltered in HL rats, which showed osteopenia (by dual-energy X-ray absorptiometry), associated
\end{abstract}

with hyperglycemia, hypertriglyceridemia, and hypercholesterolemia. GLP-1 or Ex-4 administration decreased the levels of glucose, triglycerides, and total cholesterol in plasma but increased osteocalcin (OC) gene expression and the osteoprotegerin (OPG)/receptor activator of $\mathrm{NF}-\kappa \mathrm{B}$ ligand (RANKL) ratio - at the expense of an augmented $\mathrm{OPG}-$ above corresponding control values in the tibia. Each tested peptide similarly reversed the decreased femoral and vertebral bone mass in these rats, whereas the deteriorated trabecular structure in the vertebrae improved associated with normalization of bone remodeling. These findings demonstrate that GLP-1 and Ex-4 are similarly efficient in reversing the bone alterations in this HL rat model, which has proven to be useful for studying the fat-bone relationships.

Journal of Endocrinology (2011) 209, 203-210

\section{Introduction}

Obesity is closely related to hypertension, insulin resistance, diabetes mellitus, and dyslipidemia, which significantly increase the risk of cardiovascular disease (see Hummasti \& Hotamisligil (2010) for review). Although obesity has been traditionally considered protective for the skeleton, increasing evidence suggests otherwise. It now seems to be clear that this apparent protection is a consequence of the mechanical loading imposed by high body weight in this condition (Rosen \& Bouxsein 2006, Pereira et al. 2007). In fact, hypercholesterolemia appears to contribute to the pathogenesis of osteoporosis in postmenopausal women, which might justify the use of cholesterol-lowering statins as putative therapies in this situation (Herrington \& Potvin Klein 2001, Tanko et al. 2003, Majima et al. 2007). In the Zucker diabetic fatty rat model, osteopenia was prevented by the administration of insulin-sensitizing agents lowering hyperlipidemia and hyperglycemia (Shibata et al. 2000). In addition, a correlation between obesity and fractures - likely a consequence of an altered bone mass and/or bone fragility has recently been reported in postmenopausal women (De Laet et al. 2005, Premaor et al. 2010). Fat and bone metabolism are functionally related through complex neuroendocrine pathways (Reid 2010) and also by the fact that adipocytes and osteoblasts share a common progenitor from bone marrow stromal cells (Rodriguez et al. 1999). In this respect, the negative bony effect of fat is particularly evident in the bone marrow milieu of aging and osteoporotic subjects, which shows high adiposity and decreased osteoblastic differentiation and bone formation (Rodriguez et al. 1999, Verma et al. 2002, Rosen \& Klibanski 2009). In addition, hyperlipidemia has been shown to promote osteoclastogenesis and bone resorption (Tintut et al. 2004). Hence, the majority of studies point to increased fat mass as an important factor contributing to poor bone quality in obese subjects (Zhao et al. 2008, Buizert et al. 2009).

It has been reported that the anti-diabetic peptides glucagon-like peptide 1 (GLP-1) and exendin 1-39 amide (Ex-4) show beneficial effects in reducing cholesterol and 
triglycerides in diabetic subjects (Klonoff et al. 2008, Rizzo et al. 2009, Horton et al. 2010). GLP-1, an incretin with insulinotropic and insulin-independent anti-diabetic properties (Creutzfeldt 2001), exerts insulin-3-like effects upon glucose metabolism in the liver, the skeletal muscle, and fat, apparently through a specific receptor different from that cloned in the pancreas (Valverde et al. 1994, Delgado et al. 1995, Villanueva-Peñacarrillo et al. 1995, Yang et al. 1998, Villanueva-Peñacarrillo et al. 2001b, Sancho et al. 2005, Arnés et al. 2008). In adipose tissue, GLP-1 has opposite actions upon lipid metabolism - lipogenic and lipolytic - which are mediated by cAMP and inositolphosphoglycan (IPG) signaling pathways respectively (Ruiz-Grande et al. 1992, Márquez et al. 1998, Villanueva-Peñacarrillo et al. 2001a). Ex-4 is a natural occurring non-mammalian peptide that shows partial homology to GLP-1 and shares with this incretin several glucose and lipid regulatory effects in both normal and diabetic states (Eng et al. 1992). However, Ex-4 has a much longer circulating half-life than GLP-1; it is resistant to degradation by dipeptidyl peptidase IV, which makes it more suitable as an anti-diabetic agent (Nielsen et al. 2004). Similar to GLP-1, Ex-4 also lowers gastric emptying and has anorectic properties (Willms et al. 1996, Szayna et al. 2000, Talsania et al. 2005).

Recently, we demonstrated that both GLP-1 and Ex-4 exert osteogenic effects in rats with either type 2 diabetes - by administering a single dose of streptozotocin on the day of birth - or fructose-induced insulin resistance, as shown by alterations in various osteoblastic genes and bone structural parameters (assessed by micro-computed tomography $(\mu \mathrm{CT})$ ) in the appendicular skeleton (Nuche-Berenguer et al. 2009, 2010a). These studies suggest that the osteogenic action of these peptides might be in part a consequence of osteoclast inhibition through changes in the osteoprotegerin (OPG)/receptor activator of NF- $\mathrm{KB}$ ligand (RANKL) ratio in osteoblasts. Moreover, it has recently been reported that GLP-1 directly interacts with specific receptors that are independent of its cAMP-linked receptor in the pancreas but dependent on IPG in an osteoblastic cell line (Nuche-Berenguer et al. 2010b). Collectively, the recently reported bony effects of GLP-1 and Ex-4, together with their known lipid-lowering action, make them candidates for improving bone health in hyperlipidemia-related conditions.

In this study, we aimed to evaluate the relative efficacy of GLP-1 and Ex-4 as osteogenic agents - by assessing bone mass and several bone turnover markers as well as bone histomorphometric parameters - in a previously characterized hyperlipidic and hypercaloric rat model (Prats et al. 1989).

\section{Materials and Methods}

\section{Reagents}

Human GLP-1 (7-36) amide and Ex-4 (Bachem AG, Bubendorf, Switzerland); porcine insulin (Novo Biolabs,
Bagsvaerd, Denmark); osmotic pumps (Alzet 1003D; Alza, Palo Alto, CA, USA); Meritene mineral and vitamin complex (Nestlé Nutrition, Barcelona, Spain); demeclocycline, TRI Reagent for RNA isolation, and anti- $\boldsymbol{\alpha}$-tubulin antibody (Sigma-Aldrich); Taqman Universal PCR master mix and high-capacity cDNA reverse transcription kit, probes and primers for rat osteocalcin (OC) (Rn00566386_g1), OPG (Rn00563499_m1), RANKL (Rn00569289_m1), and eukaryotic 18S (4319413E) (Applied Biosystems, Foster City, CA, USA); HRP-conjugated donkey anti-rabbit and anti-mouse $\operatorname{IgG}$, rainbow markers, ECL-western blotting kit, and Hyperfilm ECL (Amersham Pharmacia Biotech); rabbit polyclonal OPG and RANKL antibodies (Santa Cruz Biotechnology, Santa Cruz, CA, USA); transfer semidry system (Trans-blot SD semidry transfer cell, Bio-Rad); and methylmethacrylate (Merck Pharma Química, S.A.). All other commonly used chemicals were from Sigma-Aldrich or Merck.

\section{Animals}

We used 6-week-old male Wistar rats kept on a standard pellet diet (Panlab, Barcelona, Spain) and tap water ad libitum. Animals were divided into two dietary sets for 35 days: one group of normal rats $(\mathrm{N} ; n=6)$ was fed a standard chow $(8 \%$ calories as fat) and another group (hyperlipidemic (HL); $n=28$ ) was fed a 'cafeteria diet' consisting of standard chow combined with a daily intake of cookies, liver paste, bacon, and whole milk supplemented with sucrose $(333 \mathrm{~g} / \mathrm{l})$ and $10 \mathrm{~g} / 1$ of a mineral and vitamin complex (65\% of calories derived from lipids). All the food items were weighed daily and offered in excess to rats. This diet protocol has been shown to provide a high-energy and high-fat intake (Prats et al. 1989). A control of daily caloric intake for the 35-day period of the study was done in $12 \mathrm{HL}$ rats, by measuring the leftovers after consumption of each item in the diet, and considering their caloric density provided by the respective manufacturer.

\section{Experimental design}

To avoid possible changes associated with aging, all rats in the study were 11 weeks old by the time of each treatment as follows. We subjected two separate groups of HL rats $(n=8$ each) to a 3-day treatment (Nuche-berenguer et al. 2009, $2010 a)$ with either GLP-1 (0.86 nmol/kg per h) or Ex-4 $(0.1 \mathrm{nmol} / \mathrm{kg}$ per $\mathrm{h})$, dissolved in saline, by continuous infusion through a subcutaneously implanted osmotic pump (Alzet 1003D; Alza). Another group of HL rats $(n=12)$ were treated only with saline solution in parallel with each peptide group of animals and used as treatment controls. Some of the rats $(n=5)$ from each experimental HL group were intraperitoneally injected with demeclocycline $(20 \mathrm{mg} / \mathrm{kg})$ at days 13 and 4 before killing. Just before (basal) and at the end of the 3-day peptide (or saline) treatments, blood samples were collected from the rat tail for measuring plasma glucose, 
insulin, cholesterol, triglycerides, and calcium and creatinine. Afterward, the animals were stunned and killed by a sharp blow to the head; the tibiae were quick-frozen and stored at $-70{ }^{\circ} \mathrm{C}$ until total RNA and protein isolation; femurs and L1-L4 vertebrae were also collected, stripped of soft tissue, and kept in $70 \%$ ethanol for the analysis of bone mineral density (BMD), bone mineral content (BMC), and/or bone histomorphometry. Animal housing and protocols were approved by the Animal Use Committee of the Instituto de Investigación Sanitaria (IIS)-Fundación Jiménez Díaz.

\section{Plasma measurements}

Glucose was determined by the glucose oxidase method (Glucose analyzer 2; Beckman, Galway, Ireland); insulin was measured by RIA (Herbert et al. 1965, Valverde et al. 1988), using rat insulin (Linco, St Charles, MO, USA) as standard; cholesterol and triglycerides were assayed by an automatic analyzer (Advia 1200, Siemens, Bayer).

\section{Isolation of total bone RNA and real-time PCR}

The quick-frozen rat tibiae were individually powdered with a cold steel mortar and pestle and then mixed with TRI Reagent for total RNA extraction, following the manufacturer's instructions. Total RNA concentration and purity were estimated by absorbance at 260 and $280 \mathrm{~nm}$, respectively, in an aliquot volume of each sample. cDNA was synthesized from $4 \mu \mathrm{g}$ total bone RNA using avian myeloblastosis virus reverse transcriptase (Promega) with random hexamer primers. PCR amplification was carried out in a StepOne system (Applied Biosystems), in triplicate for each sample, in a total volume of $20 \mu \mathrm{l}$ containing $400 \mathrm{ng}$ of cDNA, $900 \mathrm{nM}$ of each primer, $500 \mathrm{nM}$ of the respective probe, and $6 \mu \mathrm{l}$ of TaqMan Universal PCR Master Mix, as described previously (Nuche-Berenguer et al. 2009, $2010 a$ ). For each rat, the gene expression was normalized with that of the housekeeping gene $18 \mathrm{~S}$ and expressed as $2^{-\Delta \Delta C_{\mathrm{T}}}$.

\section{Immunoblotting}

Total proteins from the rat tibiae were isolated, following a previously described protocol (Moreno-Rubio et al. 2010). Protein content in bone tissue extracts was determined by the Bradford's method (Pierce, Rockford, IL, USA), using BSA as standard. Equal amounts of proteins $(30 \mu \mathrm{g}$ for OPG and $60 \mu \mathrm{g}$ for RANKL) were separated on $8 \%$ polyacrylamideSDS gels under reducing conditions. After electrophoresis, the samples were transferred onto nitrocellulose membranes in a Trans-blot SD semidry transfer cell (Bio-Rad). For immunodetection, OPG and RANKL antibodies and anti$\boldsymbol{\alpha}$-tubulin were used as primary antibodies and a HRP-conjugated donkey anti-rabbit or anti-mouse $\operatorname{IgG}$ as secondary antibodies, subsequently followed by enhanced chemiluminescence and quantification by densitometry scanning of the autoradiogram, according to a standard protocol (Redondo et al. 2003). The densitometry values of the bands corresponding to OPG and RANKL protein were normalized with respect to that of $\boldsymbol{\alpha}$-tubulin.

\section{Dual-energy X-ray absorptiometry and bone histomorphometry}

BMD and BMC were determined in the total femur and lumbar spine (L1-L4) of each rat by using a PIXImus X-ray densitometer (GE Lunar Corp., Madison, WI, USA). The vertebral bone specimens were dehydrated in graded ethanols and embedded in methylmethacrylate. Sagittal longitudinal sections $(7 \mu \mathrm{m}$ thick) of the vertebrae were obtained with a rotation microtome for hard materials (Leica RM2255, Leica Microsystems, Nussloch, Germany) and were stained with von Kossa and Goldner's trichrome for the analysis of static parameters (Campodarve et al. 1993). From each biopsy, two sections were kept unstained for subsequent fluorescence microscopy examination (analysis of dynamic parameters). Histomorphometric measurements were performed using a light microscope with reticule-mounted eyepiece grid, and variables were calculated following the American Society for Bone and Mineral Research recommendations (Parfitt et al. 1987). The mineralized surface was calculated as: (double label surface $+0 \cdot 5$ single labeled surface)/bone surface (MS/ BS). Mineral apposition rate (MAR) and bone formation rate (BFR) were calculated as the separation between two labels/ 9 days and (MAR $\times$ MS/BS) respectively.

\section{Statistical analysis}

Results are expressed as mean \pm s.E.M., together with the number of observations. The statistical significance $(P<0 \cdot 05)$ of the increments was assessed either by one-way ANOVA followed by the least significant differences test for post-hoc multiple comparisons or Student's $t$-test when appropriate, using the Statistical Package for the Social Science (SPSS) software (SPSS Inc., Chicago, IL, USA).

Table 1 Body weight and plasma measurements in normal rats $(\mathrm{N})$, and in hyperlipidemic rats (HL) before (basal) and after 3-day treatment with GLP-1 or Ex-4. Date are mean \pm s.E.M. $(n=8)$

\begin{tabular}{|c|c|c|c|c|}
\hline & \multirow{2}{*}{$\frac{\mathbf{N}}{\text { Basal }}$} & \multicolumn{3}{|l|}{ HL } \\
\hline & & Basal & GLP-1 & Ex-4 \\
\hline Glucose (mg/dl) & $102 \pm 2$ & $115 \pm 3^{*}$ & $107 \pm 4$ & $100 \pm 3^{+}$ \\
\hline Insulin (ng/ml) & $1 \cdot 6 \pm 0 \cdot 3$ & $1 \cdot 3 \pm 0 \cdot 2$ & $1 \cdot 0 \pm 0 \cdot 1$ & $1 \cdot 3 \pm 0 \cdot 4$ \\
\hline $\begin{array}{l}\text { Total cholesterol } \\
(\mathrm{mg} / \mathrm{dl})\end{array}$ & $67 \pm 4$ & $94 \pm 5^{*}$ & $81 \pm 2^{+}$ & $82 \pm 3^{+}$ \\
\hline $\begin{array}{l}\text { Triglycerides } \\
\text { (mg/dl) }\end{array}$ & $105 \pm 5$ & $147 \pm 17^{*}$ & $83 \pm 7^{+}$ & $95 \pm 9^{+}$ \\
\hline Weight (g) & $315 \pm 7$ & $337 \pm 9$ & $349 \pm 10$ & $322 \pm 8$ \\
\hline
\end{tabular}

${ }^{*} P<0 \cdot 05$ versus $\mathrm{N}$ basal value; ${ }^{\dagger} P<0.05$ versus respective $\mathrm{HL}$ basal value. 


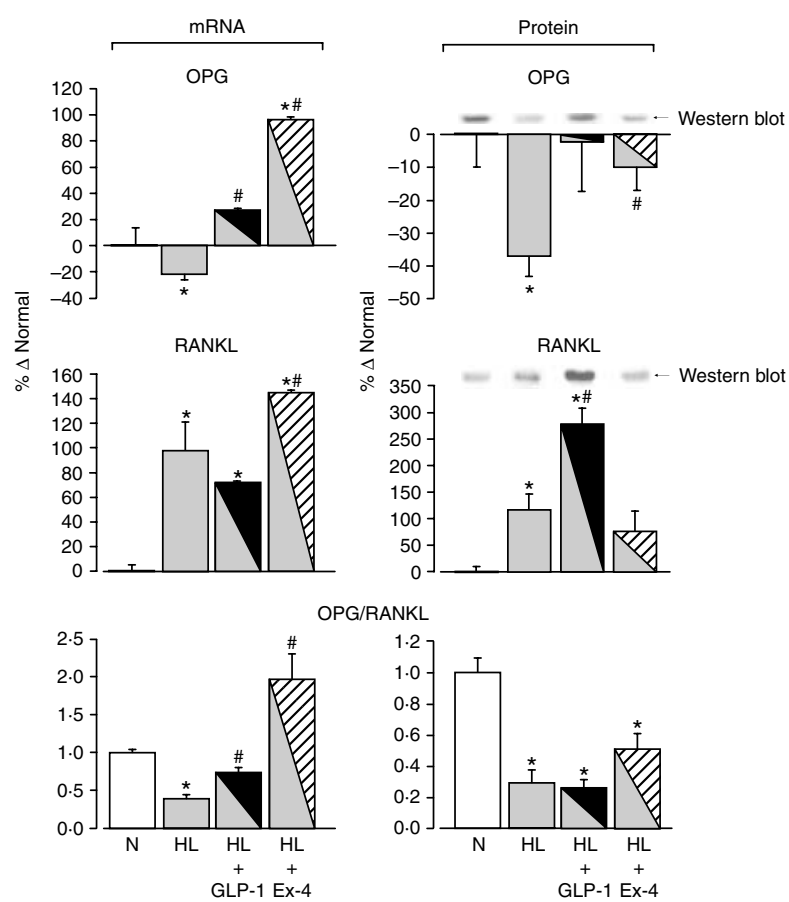

Figure 1 OPG and RANKL mRNA and protein expression in the tibia of normal $(\mathrm{N})$ and hyperlipidemic $(\mathrm{HL})$ rats, untreated (grey) or treated with GLP-1 (black) or Ex-4 (white) as described in the text. OPG and RANKL mRNA levels (assessed by real-time PCR) were calculated as copy numbers by using the Ct value relative to that in $\mathrm{N}$ rats, after normalization against $18 S$ rRNA $\left(2^{-\Delta \Delta C_{\mathrm{T}}}\right)$ value. Protein levels (evaluated by western blot), corresponding to densitometry values of bands normalized to that of $\alpha$ tubulin, were expressed as percent increment of those of the $\mathrm{N}$ group. Representative autoradiogram images, which were grouped from different parts of the same gel, are shown in each case (western blot). Protein loading was similar in each well, as assessed by Ponceau $S$ staining (not shown). Data are mean \pm s.E.M. corresponding to $8-12$ rats. ${ }^{*} P<0.05$ or lower versus $N$; $\# P<0.05$ or lower versus HL.

\section{Results}

\section{Plasma measurements}

As expected (Prats et al. 1989), HL rats showed hyperglycemia, hypertriglyceridemia, and hypercholesterolemia compared with those in the $\mathrm{N}$ group (overall mean increase of these parameters: $37 \pm 5 \% \mathrm{~N}$-rats, $P<0 \cdot 02)$. A 3-day treatment of HL rats with either GLP-1 or Ex-4 induced a significant decrease in total cholesterol and plasma triglycerides; glycemia was also reduced, but only significantly for Ex-4 (Table 1). No significant differences were detected in body weight or plasma insulin between $\mathrm{N}$ and HL rats throughout the study. Plasma calcium and creatinine were also similar in HL and $\mathrm{N}$ rats and unchanged by either peptide treatment (not shown), as expected from our previous findings (Nuche-Berenguer et al. 2009, 2010a).
Expression of bone markers

In HL rats (Fig. 1), OC mRNA levels were similar (95 \pm 8\%) to those in $\mathrm{N}$ animals (100\%), and both GLP-1 and Ex-4 treatments increased the value to $206 \pm 30$ and $239 \pm 30 \%$ respectively $(P<0 \cdot 01)$. OPG (both $\mathrm{mRNA}$ and protein) expression was lower in the HL rats than in the $\mathrm{N}$ group, and this downregulation was reversed by both GLP-1 and Ex-4 administration (Fig. 1). In contrast, RANKL (both gene and protein) expression in the HL rats was higher than that in the $\mathrm{N}$ group, and although GLP-1 failed to modify the RANKL mRNA value, Ex-4 treatment increased it even further; meanwhile, GLP-1, but not Ex-4, stimulated RANKL protein over that in the HL group. As a consequence, the OPG/RANKL ratio (both mRNA and protein) in the HL rats (Fig. 1) was lower than that in the $\mathrm{N}$ group, and it rose after GLP-1 and Ex-4 treatment, mainly accounted for by changes in OPG expression.

\section{Bone mass analysis}

Figure 2 shows the values of BMD and BMC in the femur and lumbar spine of HL rats, treated or untreated with GLP-1 or Ex-4, compared with those in the $\mathrm{N}$ group. At both the skeletal sites, BMD and BMC values in the HL group were significantly lower than those in the $\mathrm{N}$ rats, which were $168 \pm 3$ and $169 \pm 7 \mathrm{mg} / \mathrm{cm}^{3}$ (femur) and $358 \pm 16$ and $546 \pm 53$ (vertebrae) respectively. Both GLP-1 and Ex-4 similarly reversed this decrease in BMD and BMC in the femur and vertebrae in these rats. At the latter site, the increase induced by both peptides tested on these bone mass parameters represented (overall mean) $21 \pm 3$ and $29 \pm 5 \% \mathrm{HL}$ value $(P<0 \cdot 001)$ respectively.

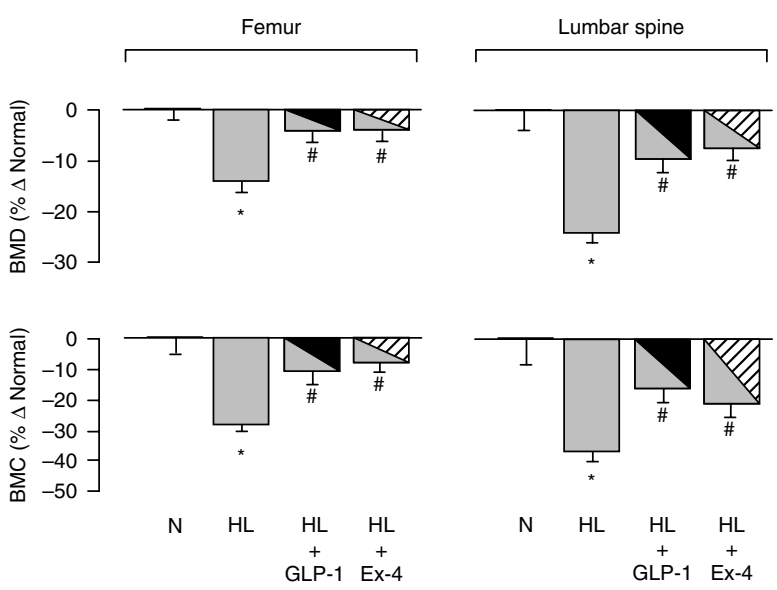

Figure 2 Changes in $\mathrm{BMD}$ and $\mathrm{BMC}$ in the total femur and lumbar spine (L1-L4), of normal (N) and hyperlipidemic (HL) rats, untreated (grey) or treated with GLP-1 (black) or Ex-4 (white) as described in the text. Data (mean \pm S.E.M.; $n=8-12$ rats) are expressed as percent increment of the value obtained in the $\mathrm{N}$ group.

$* P<0.05$ or lower versus $N$; \#P<0.05 or lower versus HL. 
Table 2 Histomorphometric analysis of trabecular regions at the lumbar spine from normal $(\mathrm{N})$ and hyperlipidemic (HL) rats, untreated or treated with GLP-1 or Ex-4. Data are mean \pm S.E.M. ( $n=5$ rats/group)

\begin{tabular}{|c|c|c|c|c|}
\hline & $\mathbf{N}$ & HL & HL + GLP-1 & $H L+E x-4$ \\
\hline \multicolumn{5}{|l|}{ Static parameters } \\
\hline BV/TV (\%) & $32 \cdot 2 \pm 4 \cdot 6$ & $19 \cdot 2 \pm 2 \cdot 0^{*}$ & $31 \cdot 8 \pm 1 \cdot 2^{\dagger}$ & $31 \cdot 4 \pm 2 \cdot 1^{+}$ \\
\hline Tb.Th $(\mu \mathrm{m})$ & $527 \pm 24$ & $377 \pm 22 *$ & $505 \pm 18^{+}$ & $737 \pm 109^{\dagger}$ \\
\hline Tb.Sp $(\mu \mathrm{m})$ & $1186 \pm 202$ & $1749 \pm 94^{*}$ & $1092 \pm 72^{+}$ & $1422 \pm 168$ \\
\hline Tb. $N\left(\mathrm{~mm}^{-1}\right)$ & $0 \cdot 60 \pm 0 \cdot 06$ & $0 \cdot 47 \pm 0 \cdot 02$ & $0.63 \pm 0.04$ & $0 \cdot 49 \pm 0.06$ \\
\hline ES/BS (\%) & $13 \cdot 8 \pm 2 \cdot 2$ & $44 \cdot 7 \pm 5 \cdot 5^{*}$ & $11 \cdot 2 \pm 0 \cdot 5^{+}$ & $13 \cdot 3 \pm 2 \cdot 8^{\dagger}$ \\
\hline OcS/BS (\%) & $4 \cdot 0 \pm 1 \cdot 2$ & $20 \cdot 7 \pm 2 \cdot 1^{*}$ & $2 \cdot 2 \pm 0 \cdot 1^{+}$ & $3 \cdot 2 \pm 0 \cdot 9^{\dagger}$ \\
\hline n. Oc/TA $\left(\mathrm{mm}^{2}\right)$ & $0 \cdot 17 \pm 0 \cdot 03$ & $0 \cdot 48 \pm 0 \cdot 03 *$ & $0 \cdot 11 \pm 0 \cdot 01^{\dagger}$ & $0.12 \pm 0.03^{+}$ \\
\hline MS/BS (\%) & $78 \cdot 4 \pm 4 \cdot 7$ & $78 \cdot 6 \pm 10 \cdot 8$ & $58 \cdot 9 \pm 2 \cdot 5$ & $71 \cdot 2 \pm 2 \cdot 9$ \\
\hline OV/TV (\%) & $18 \cdot 9 \pm 2 \cdot 5$ & $27 \cdot 8 \pm 5 \cdot 3$ & $5 \cdot 4 \pm 1 \cdot 5^{+}$ & $4 \cdot 3 \pm 0 \cdot 4^{+}$ \\
\hline OS/BS (\%) & $1 \cdot 3 \pm 0 \cdot 1$ & $1 \cdot 8 \pm 0 \cdot 3$ & $0 \cdot 6 \pm 0 \cdot 2^{+}$ & $1 \cdot 0 \pm 0 \cdot 2$ \\
\hline $\mathrm{ObS} / \mathrm{BS}(\%)$ & $6 \cdot 1 \pm 1 \cdot 1$ & $11 \cdot 0 \pm 0 \cdot 9 *$ & $4 \cdot 8 \pm 0 \cdot 3^{+}$ & $6 \cdot 5 \pm 0 \cdot 9^{+}$ \\
\hline \multicolumn{5}{|c|}{ Dynamic parameters } \\
\hline MAR ( $\mu \mathrm{m} /$ day $)$ & $0 \cdot 39 \pm 0 \cdot 01$ & $0 \cdot 56 \pm 0 \cdot 07^{*}$ & $0 \cdot 45 \pm 0.02$ & $0 \cdot 36 \pm 0 \cdot 02^{+}$ \\
\hline BFR/BS ( $\mu \mathrm{m} /$ day) & $0 \cdot 34 \pm 0 \cdot 03$ & $0 \cdot 49 \pm 0.06 *$ & $0 \cdot 26 \pm 0.02^{+}$ & $0 \cdot 27 \pm 0 \cdot 01^{\dagger}$ \\
\hline
\end{tabular}

${ }^{*} P<0 \cdot 05$ or lower versus $\mathrm{N},{ }^{+} P<0 \cdot 05$ or lower versus $\mathrm{HL}$. BV/TV, bone volume per total tissue volume ratio; Tb.Th, trabecular thickness; Tb.Sp, trabecular separation; Tb.N, trabecular number; ES, erosive surface; BS, bone surface; OcS, osteoclast surface; n.Oc/TA, osteoclast number per total area ratio; MS, mineralized surface; OV, osteoid volume; OS, osteoid surface; ObS, osteoblast surface; MAR, mineral apposition rate; BFR, bone formation rate.

\section{Bone histomorphometry}

Alterations in the trabecular area of the lumbar spine were detected in the HL rats. These included a lower bone volume per total tissue volume ratio $(\mathrm{BV} / \mathrm{TV})$ and trabecular thickness (Tb.Th) values as well as a higher trabecular separation (Tb.Sp) (Table 2 and Fig. 3A), compared with those in the $\mathrm{N}$ rats. Furthermore, an increase in MAR and in $\mathrm{BFR}$ - together with an increased osteoblast surface (ObS)/ BS - was observed in the lumbar vertebrae in these animals (Table 2). In fact, tetracycline double labels were more abundant than single labels in HL rats than in their controls
(Fig. 3B), which has probably resulted in a certain overestimation of MAR in the former animals (Foldes et al. 1990). In addition, an increase in the number of erosive surfaces with abundant osteoclasts occurred at this skeletal site in this group of rats. Both GLP-1 and Ex-4 elicited a clear osteogenic action, as assessed by changes in $\mathrm{BV} / \mathrm{TV}$ and several trabecular parameters at the lumbar spine of $\mathrm{HL}$ rats (Table 2 and Fig. 3A). This action is likely related to a decrease in bone remodeling; in fact, bone formation parameters normalized or even decreased below normal values in the lumbar vertebrae of $\mathrm{HL}$ rats after treatment with these peptides (Table 2 and Fig. 3B).

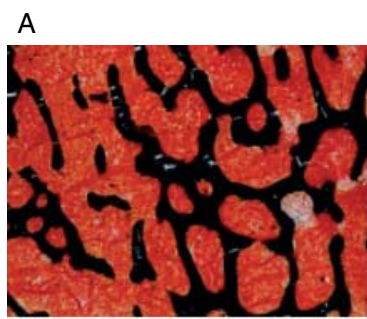

$\mathrm{N}$

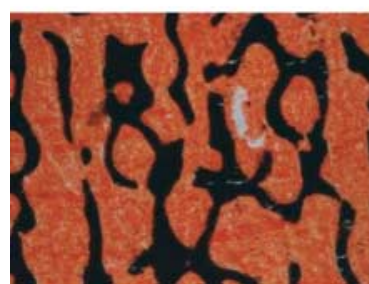

$\mathrm{HL}+\mathrm{GLP}-1$

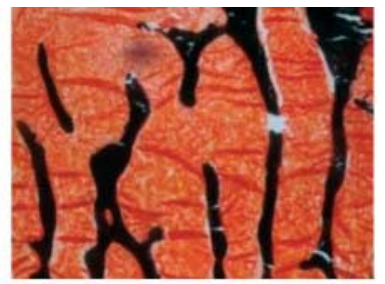

$\mathrm{HL}$

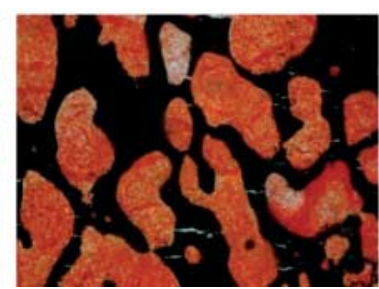

$\mathrm{HL}+\mathrm{Ex}-4$

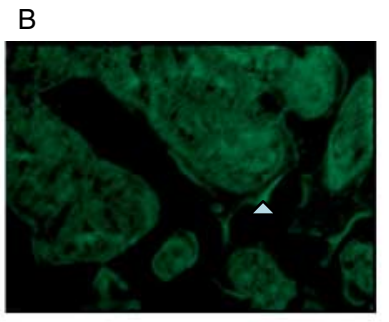

$\mathrm{N}$

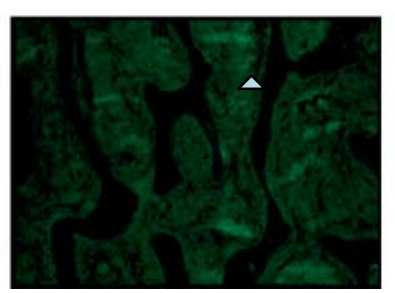

$\mathrm{HL}+\mathrm{GLP}-1$

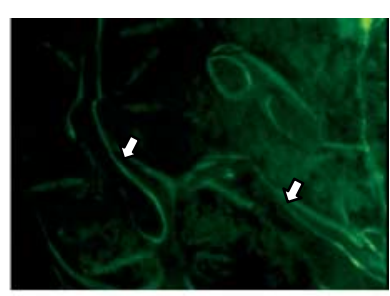

$\mathrm{HL}$

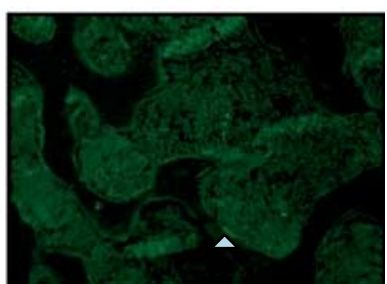

$\mathrm{HL}+\mathrm{Ex}-4$

Figure 3 Light microscopy images showing the trabecular structure using von Kossa's staining (A), and single (arrowheads) and double (arrows) demeclocycline labels (B), in the lumbar vertebrae from representative normal $(\mathrm{N})$ and hyperlipidemic $(\mathrm{HL})$ rats, untreated or treated with GLP-1 or Ex-4. Original magnifications, $\times 400$. 


\section{Discussion}

The old concept of bone and fat as inert metabolic tissues has been reconsidered in the light of recent findings showing that bone is able to modulate energy metabolism while adipokines exert an important influence on the mechanisms of bone mass maintenance (Lee et al. 2007). Moreover, the use of drugs for the treatment of metabolic disorders, such as type 2 diabetes and atherosclerosis, has shown to impact bone metabolism (Herrington \& Potvin Klein 2001, Majima et al. 2007). In this regard, we recently reported that both GLP-1 and Ex-4 have osteogenic effects in two insulin resistance and type 2 diabetic rat models (Nuche-Berenguer et al. 2009, 2010a). In addition, the former incretin has been shown to directly interact with osteoblastic cells in vitro by interaction with a specific receptor different from that which is well characterized in the pancreas (NucheBerenguer et al. 2010b).

The HL model used in this study, showing the metabolic characteristics of obesity without changes in body weight, is of particular interest because it prevents the deleterious effects of hyperlipidemia from being overshadowed by a putative opposing action of body weight gain upon bone metabolism. Both femora and vertebrae displayed a diminished BMD and BMC and the OPG/RANKL ratio was reduced in the tibia in $\mathrm{HL}$ rats, suggesting a deleterious bone metabolism in this model. This was confirmed by performing bone histomorphometry in trabecular bone areas in the lumbar vertebrae of these rats, showing lower BV/TV and reduced $\mathrm{Tb} . \mathrm{Th}$, probably as a consequence of an increased bone resorption.

Recently, we showed that continuous infusion of GLP-1 and Ex-4 for 3 days into insulin-resistant or type 2 diabetic rats ameliorated the altered trabecular structure (evaluated by $\mu \mathrm{CT})$, related to an increase in $O P G / R A N K L$ gene ratio in the long bone (Nuche-Berenguer et al. 2009, 2010a). In this study, the same administration scheme of GLP-1 and Ex-4 into HL rats was shown to induce similar osteogenic effects as indicated by BMD and BMC increases in both femur and vertebrae, associated with changes in various trabecular structure parameters at the latter skeletal location. These changes were associated with the anti-resorptive features displayed by both peptides as depicted by bone histomorphometry and also by the observed changes in the OPG/ RANKL ratio. Furthermore, as it was the case in the aforementioned T2D and IR models (Nuche-Berenguer et al. 2010a), Ex-4 was found to stimulate this ratio in HL rats even above than that in the normal group, also supporting the higher efficiency of Ex-4 with respect to GLP-1 in this model.

These aggregated findings, using different techniques to evaluate bone structure ( $\mu \mathrm{CT}$ and histomorphometry) and different rat models showing glucose and energy metabolism alterations, demonstrate that a short length of treatment with the tested peptides can exert positive effects on the trabecular bone at different skeletal sites. Our present data strongly suggest that the anti-resorptive properties of GLP-1, consistent with those previously reported in a different experimental setting (Yamada et al. 2008), and that of its homologous peptide Ex-4 as shown here, are mainly responsible for their observed osteogenic action in HL rats.

It is currently intriguing whether these peptides might be able to directly target bone formation leading to anabolic effects in bone. Recent studies in diabetic rats (NucheBerenguer et al. 2009, 2010a) might support this notion, although an earlier report in knockout mice for the pancreatic GLP-1 receptor had suggested otherwise (Yamada et al. 2008). Also of interest in this regard, GLP-1, acting through the pancreatic GLP-1 receptor, has recently been shown to prevent the differentiation of human bone marrow stromal cells into adipocytes (Sanz et al. 2010); however, this study did not examine whether osteogenic differentiation might have been concomitantly induced by this peptide in these cells. Regarding the latter, we recently found that GLP-1 can directly upregulate $O C$ gene expression in mouse osteoblastic MC3T3-E1 cells. It is presently unclear whether the effects of GLP-1 and Ex-4, as observed in this study and in our previous reports (Nuche-Berenguer et al. 2009, 2010a), are due to their interaction with different receptors and/or signaling in bone cells; in fact, a specific receptor for GLP-1, which is unrelated to the pancreatic GLP-1 receptor and does not bind Ex-4, has been described in osteoblastic cells (Nuche-Berenguer et al. 2010b).

In conclusion, the present findings indicate that this previously characterized HL model exhibits skeletal changes related to bone loss; thus, it can be a valuable model for studies to explore fat-bone relationships. Our findings also demonstrate that both GLP-1 and Ex-4 can reverse the bone alterations by inhibiting bone remodeling in HL rats, suggesting that these peptides could be envisioned as putative therapeutic agents to improve bone health in hyperlipidic states.

\section{Declaration of interest}

The authors declare that there is no conflict of interest that could be perceived as prejudicing the impartiality of the research reported.

\section{Funding}

This work was supported by CIBERDEM, Red Temática d e Investigación Cooperativa en Envejecimiento y Fragilidad (RETICEF; RD06/0013/1002), and grants from Instituto de Salud Carlos III (PI 060076 and PI 080922) and Ministerio de Ciencia e Innovación (CP08/00158) of Spain. B N-B, D L and $\mathrm{P}$ M are research fellows from Fundación Conchita Rábago de Jiménez Díaz; I G-R is the recipient of a CIBERDEM contract.

\section{Acknowledgements}

We thank Estrella Martín-Crespo for excellent technical assistance, Adolfo Díez-Pérez for helpful criticisms, and Mark Davis for proofreading the manuscript. 


\section{References}

Arnés L, González N, Tornero-Esteban P, Sancho V, Citores AA, Valverde I, Delgado E \& Villanueva-Penacarrillo ML 2008 Characteristics of GLP-1 and exendins action upon glucose transport and metabolism in type 2 diabetic rat skeletal muscle. International Journal of Molecular Medicine 22 127-132.

Buizert PJ, van Schoor NM, Lips P, Deeg DJ \& Eekhoff EM 2009 Lipid levels: a link between cardiovascular disease and osteoporosis? Journal of Bone and Mineral Research 24 1103-1109. (doi:10.1359/jbmr. 081262)

Campodarve I, Díez A, Puig J, Serrano S, Mariñoso ML, Arnau MD, Cucurull J, Ibáñez J, Nogués X \& Aubia J 1993 Correlation between densitometric and hystomorphometric values in isolated vertebrae of Sprague-Dawley rats. Calcified Tissue International 52 470-471. (doi:10.1007/BF00571339)

Creutzfeldt W 2001 The entero-insular axis in type 2 diabetes - incretins as therapeutic agents. Experimental and Clinical Endocrinology and Diabetes 109 S288-S303. (doi:10.1055/s-2001-18589)

De Laet C, Kanis JA, Oden A, Johanson H, Johnell O, Delmas P, Eisman JA, Kroger H, Fujiwara S, Garnero P et al. 2005 Body mass index as a predictor of fracture risk: a meta-analysis. Osteoporosis International 16 1330-1338. (doi:10.1007/s00198-005-1863-y)

Delgado E, Luque MA, Alcántara A Trapote MA, Clemen te F, Galera C, Valverde I \& Villanueva-Peñacarrillo ML 1995 Glucagon-like peptide-1 binding to rat skeletal muscle. Peptides 16 225-229. (doi:10.1016/01969781(94)00175-8)

Eng J, Kleinman WA, Singh L, Singh G \& Raufman JP 1992 Isolation and characterization of exendin- 4 , an exendin-3 analogue, from heloderma suspectum venom. Further evidence for an exendin receptor on dispersed acini from guinea pig pancreas. Journal of Biological Chemistry 267 $7402-7405$.

Foldes J, Shih M-S \& Parfitt AM 1990 Frequency distribution of tetracyclinebased measurements: implications for the interpretation of bone formation indices in the absence of double-labeled surfaces. Journal of Bone and Mineral Research 5 1063-1067. (doi:10.1002/jbmr.5650051010)

Herbert VLKS, Goltlieb CW \& Bleicher SJ 1965 Coated charcoal inmunoassay of insulin. Journal of Clinical Endocrinology and Metabolism 25 1375-1384. (doi:10.1210/jcem-25-10-1375)

Herrington DM \& Potvin Klein K 2001 Statins, hormones, and women: benefits and drawbacks for atherosclerosis and osteoporosis. Current Atherosclerosis Reports 3 35-42. (doi:10.1007/s11883-001-0008-9)

Horton ES, Silberman C, Davis KL \& Berria R 2010 Weight loss, glycemic control, and changes in cardiovascular biomarkers in patients with type 2 diabetes receiving incretin therapies or insulin in a large cohort database. Diabetes Care 33 1759-1765. (doi:10.2337/dc09-2062)

Hummasti S \& Hotamisligil GS 2010 Endoplasmic reticulum stress and inflammation in obesity and diabetes. Circulation Research 107 579-597. (doi:10.1161/CIRCRESAHA.110.225698)

Klonoff DC, Buse JB, Nielsen LL, Guan X, Bowlus CL, Holcombe JH, Wintle ME \& Maggs DG 2008 Exenatide effects on diabetes, obesity, cardiovascular risk factors and hepatic biomarkers in patients with type 2 diabetes treated for at least 3 years. Current Medical Research and Opinion 24 275-286. (doi:10.1185/030079907X253870)

Lee NK, Sowa H, Hinoi E, Ferron M, Ahn JD, Confavreux C, Dacquin R, Mee PJ, McKee MD, Jung DY et al. 2007 Endocrine regulation of energy metabolism by the skeleton. Cell 130 456-469. (doi:10.1016/j.cell.2007. 05.047)

Majima T, Komatsu Y, Fukao A, Ninomiya K, Matsumura T \& Nakao K 2007 Short-term effects of atorvastatin on bone turnover in male patients with hypercholesterolemia. Endocrine Journal 54 145-151. (doi:10.1507/endocrj. K06-127)

Márquez L, Trapote MA, Luque MA, Valverde I \& Villa nueva-Peñacarrillo ML 1998 Inositolphosphoglycans possibly mediate the effects of glucagon-like peptide-1(7-36)amide on rat liver and adipose tissue. Cell Biochemistry and Function 16 51-56. (doi:10.1002/(SICI)1099-0844 (199803)16:1<51::AID-CBF767> 3.0.CO;2-T)
Moreno-Rubio J, Herrero-Beaumont G, Tardío L, Alvarez-Soria MA \& Largo R 2010 Nonsteroidal antiinflammatory drugs and prostaglandin E(2) modulate the synthesis of osteoprotegerin and RANKL in the cartilage of patients with severe knee osteoarthritis. Arthritis and Rheumatism 62 478-488. (doi:10.1002/art.27204)

Nielsen LL, Young AA \& Parkes DG 2004 Pharmacology of exenatide (synthetic exendin-4): a potential therapeutic for improved glycemic control of type 2 diabetes. Regulatory Peptides 117 77-88. (doi:10.1016/ j.regpep.2003.10.028)

Nuche-Berenguer B, Moreno P, Esbrit P, Dapia S, Caeiro JR, Cancelas J, Haro-Mora JJ \& Villanueva-Penacarrillo ML 2009 Effect of GLP-1 treatment on bone turnover in normal, type 2 diabetic, and insulin-resistant states. Calcified Tissue International 84 453-461. (doi:10.1007/s00223-0099220-3)

Nuche-Berenguer B, Moreno P, Portal-Núñez S, Dapía S, Esbrit P \& Villanueva-Peñacarrillo ML 2010a Exendin-4 exerts osteogenic actions in insulin-resistant and type 2 diabetic states. Regulatory Peptides 159 61-66. (doi:10.1016/j.regpep.2009.06.010)

Nuche-Berenguer B, Portal-Núñez S, Moreno P, Gonzalez N, Acitores A, Lopez-Herradon A, Esbrit P, Valverde I, Villanueva-Penacarrillo ML, Portal-Núnez S et al. 2010b Presence of a functional receptor for GLP-1 in osteoblastic cells, independent of the cAMP-linked GLP-1 receptor. Journal of Cellular Physiology 225 585-592. (doi:10.1002/jcp.22243)

Parfitt AM, Drezner MK, Glorieux FH, Kanis JA, Malluche H, Meunier PJ, Ott SM \& Recker RR 1987 Bone histomorphometry: standardization of nomenclature, symbols, and units. Report of the ASBMR Histomorphometry Nomenclature Committee. Journal of Bone and Mineral Research 2 595-610. (doi:10.1002/jbmr.5650020617)

Pereira FA, de Castro JA, dos Santos JE, Foss MC \& Paula FJ 2007 Impact of marked weight loss induced by bariatric surgery on bone mineral density and remodeling. Brazilian Journal of Medical and Biological Research $\mathbf{4 0}$ 509-517. (doi:10.1590/S0100-879X2006005000074)

Prats E, Monfar M, Castella J, Iglesias R \& Alemany M 1989 Energy intake of rats fed a cafeteria diet. Physiology and Behavior 45 227-263. (doi:10.1016/ 0031-9384(89)90128-5)

Premaor MO, Pilbrow L, Tonkin C, Parker RA \& Compston J 2010 Obesity and fractures in postmenopausal women. Journal of Bone and Mineral Research 25 292-297. (doi:10.1359/jbmr.091004)

Redondo A, Trigo MV, Acitores A, Valverde I \& Villanueva-Peñacarrillo ML 2003 Cell signalling of the GLP-1 action in rat liver. Molecular and Cellular Endocrinology 204 43-50. (doi:10.1016/S0303-7207(03)00146-1)

Reid IR 2010 Fat and bone. Archives of Biochemistry and Biophysics 503 20-27. (doi:10.1016/j.abb.2010.06.027)

Rizzo M, Rizvi AA, Spinas GA, Rini GB \& Berneis K 2009 Glucose lowering and anti-atherogenic effects of incretin-based therapies: GLP-1 analogues and DPP-4-inhibitors. Expert Opinion on Investigational Drugs 18 1495-1503. (doi:10.1517/14728220903241633)

Rodriguez JP, Garat S, Gajardo H, Pino AM \& Seitz G 1999 Abnormal osteogenesis in osteoporotic patients is reflected by altered mesenchymal stem cells dynamics. Journal of Cellular Biochemistry $\mathbf{7 5}$ 414-423. (doi:10.1002/(SICI)1097-4644(19991201)75:3 < 414::AIDJCB7 > 3.0.CO;2-C)

Rosen CJ \& Bouxsein ML 2006 Mechanisms of disease: is osteoporosis the obesity of bone? Nature Clinical Practice. Rheumatology 2 35-43. (doi:10. 1038/ncprheum0070)

Rosen CJ \& Klibanski A 2009 Bone, fat, and body composition: evolving concepts in the pathogenesis of osteoporosis. American Journal of Medicine 122 409-414. (doi:10.1016/j.amjmed.2008.11.027)

Ruiz-Grande C, Alarcón C, Mérida E \& Valverde I 1992 Lipolytic action of glucagon-like peptides in isolated rat adipocytes. Peptides 13 13-16. (doi:10.1016/0196-9781(92)90134-O)

Sancho V, Trigo MV, Gonzalez N, Valverde I, Malaisse WJ \& VillanuevaPenacarrillo ML 2005 Effects of glucagon-like peptide-1 and exendins on kinase activity, glucose transport and lipid metabolism in adipocytes from normal and type-2 diabetic rats. Journal of Molecular Endocrinology 35 27-38. (doi:10.1677/jme.1.01747)

Sanz C, Vázquez P, Blázquez C, Barrio PA, Alvarez M del M \& Blázquez E 2010 Signaling and biological effects of glucagon-like peptide 1 on the 
differentiation of mesenchymal stem cells from human bone marrow. American Journal of Physiology. Endocrinology and Metabolism 298 E634-E643. (doi:10.1152/ajpendo.00460.2009)

Shibata T, Takeuchi S, Yokota S, Kakimoto K, Yonemori F \& Wakitani K 2000 Effects of peroxisome proliferator-activated receptor-alpha and -gamma agonist, JTT-501, on diabetic complications in Zucker diabetic fatty rats. British Journal of Pharmacology 130 495-504. (doi:10.1038/sj.bjp. 0703328)

Szayna M, Doyle ME, Betkey JA, Holloway HW, Spencer RG, Greig NH \& Egan JM 2000 Exendin-4 decelerates food intake, weight gain, and fat deposition in Zucker rats. Endocrinology 141 1936-1941. (doi:10.1210/en. 141.6.1936)

Talsania T, Anini Y, Siu S, Drucker DJ \& Brubaker PL 2005 Peripheral exendin-4 and peptide YY (3-36) synergistically reduce food intake through different mechanisms in mice. Endocrinology 146 3748-3756. (doi:10.1210/en.2005-0473)

Tanko LB, Bagger YZ, Nielsen SB \& Christiansen C 2003 Does serum cholesterol contribute to vertebral bone loss in postmenopausal women? Bone 32 8-14. (doi:10.1016/S8756-3282(02)00918-3)

Tintut Y, Morony S \& Demer LL 2004 Hyperlipidemia promotes osteoclastic potential of bone marrow cells ex vivo. Arteriosclerosis, Thrombosis, and Vascular Biology 24 e6-e10. (doi:10.1161/01.ATV. $0000112023.62695 .7 \mathrm{f}$ )

Valverde I, Barreto M \& Malaisse WJ 1988 Stimulation by D-glucose of protein biosynthesis in tumoral insulin-producing cells (RINm5F line). Endocrinology 122 1443-1448. (doi:10.1210/endo-122-4-1443)

Valverde I, Morales M, Clemente F, López-Delgado MI, Delgado E, Perea A \& Villanueva-Peñacarrillo ML 1994 Glucagon-like peptide 1: a potent glycogenic hormone. FEBS Letters 349 313-316. (doi:10.1016/00145793(94)00699-7)

Verma S, Rajaratnam JH, Denton J, Hoyland JÁ \& Byer s RJ 2002 Adipocytic proportin of bone marrow is inversely related to bone formation in osteoporosis. Journal of Clinical Pathology 55 693-698. (doi:10.1136/jcp.55. 9.693)
Villanueva-Peñacarrillo ML, Delgado E, Trapote MA, Alcántara A, Clemente F, Luque MA, Perea A \& Valverde I 1995 Glucagon-like peptide-1 binding to rat hepatic membranes. Journal of Endocrinology 146 183-189. (doi:10.1677/joe.0.1460183)

Villanueva-Peñacarrillo ML, Márquez L, González N, Díaz-Miguel M \& Valverde I 2001 a Effect of GLP-1 on lipid metabolism in human adipocytes. Hormone and Metabolic Research 33 73-77. (doi:10.1055/s-2001-12428)

Villanueva-Peñacarrillo ML, Puente J, Redondo A, Clemente F \& Valverde I $2001 b$ Effect of GLP-1 treatment on GLUT2 and GLUT4 expression in type 1 and type 2 rat diabetic models. Endocrine 15 241-248. (doi:10.1385/ ENDO:15:2:241)

Willms B, Werner J, Holst JJ, Orskov C, Creutzfeldt W \& Nauck MA 1996 Gastric emptying, glucose responses, and insulin secretion after a liquid test meal: effects of exogenous glucagon-like peptide-1 (GLP-1)-(7-36) amide in type 2 (noninsulin-dependent) diabetic patients. Journal of Clinical Endocrinology and Metabolism 81 327-332. (doi:10.1210/jc.81.1.327)

Yamada C, Yamada Y, Tsukiyama K, Yamada K, Udagawa N, Takahashi N, Tanaka K, Drucker DJ, Seino Y \& Inagaki N 2008 The murine glucagonlike peptide-1 receptor is essential for control of bone resorption. Endocrinology 149 574-579. (doi:10.1210/en.2007-1292)

Yang H, Egan JM, Wang Y, Moyes CD, Roth J, Montrose MH \& MontroseRafizadeh C 1998 GLP-1 action in L6 myotubes is via a receptor different from the pancreatic GLP-1 receptor. American Journal of Physiology 275 C675-C683.

Zhao LJ, Jiang H, Papasian CJ, Maulik D, Drees B, Hamilton J \& Deng HW 2008 Correlation of obesity and osteoporosis: effect of fat mass on the determination of osteoporosis. Journal of Bone and Mineral Research 23 17-29. (doi:10.1359/jbmr.070813)

\section{Received in final form 24 February 2011 \\ Accepted 3 March 2011 \\ Made available online as an Accepted Preprint 3 March 2011}

